\title{
France's Vocational Education and Training Reform
}

\author{
Yaoyao Zhang \\ Fujian Normal University \\ Education College \\ Fuzhou. Fujian. China, 350117
}

\begin{abstract}
Under the global background of rapidly changes in skills and production patterns, on March 5, 2018, France was actively carrying out vocational education and training reform, which focuses on three areas: apprenticeship, vocational training and unemployment insurance. On April 18 of the same year, the executive meeting of the Chinese State Council determined the relevant policies of the "lifelong vocational training system" and decided to implement the "new apprenticeship system" to promote the development of the labor force and support the upgrading of enterprises. China should understand the vocational education and training reform policies of major countries in the world before to repair vocational education and training reform programs that are in line with China's national conditions and are in line with international standards.
\end{abstract}

Keywords: France; Apprenticeship; Vocational Training; Unemployment Insurance

The Knowledge-based Economy, the globalization of the market, the development of digital technology and artificial intelligence have led to great changes in the mode of production and consumption in French society. It is report that $50 \%$ of the occupational positions in the labor market will undergo profound changes in the next decade, and skilled personnel urgently need to be transformed.(" Conceil d'orientation d'emploi synthèse du rapport, automatisation, numérisation et employ”, 2017 )On March 5, 2018, at the French Council of Ministers, the labor minister Muriel Peniko (Muriel Pénicaud) presented the Vocational Future Reform Bill (Le projet de loi Avenir professionnel), which consists of three parts: Apprenticeship Reform (Apprentissage), Vocational Training Reform (Formation professionelle) and Unemployment Insurance Reform (Assurance chômage). The reform aims to give people a new freedom of career choice and intends to develop their future professional skills. ("Le projet de loi "Avenir professionnel" présenté en conseil des ministres",2018)

\section{Background of Reform}

Since the vocational training system has not kept pace with the times and the employment rate in France has declined, it is necessary to reform vocational education and vocational training in order to solve the employment crisis in France.

\subsection{Social Development Needs}

Under the multiple effects of the country's overall economic downturn, structural employment contradiction and the polarization between rich and poor, the unemployment benefits welfare, education welfare and employment welfare of French low-income groups, the unemployed and the newly emerging youth has been significantly reduced, which further breeds social contradictions. The French government understands the role of the vocational education and training system reform in solving employment problems, promoting social development and enhancing the competitiveness of national skills.

Firstly, with the expansion of German Vocational Education 4.0's and the rise of new industries, countries have actively changed their vocational education and training systems in order to better integrate into the tide of internationalization of talents and skills. Moreover, with the deepening of the knowledge economy, the gap between the rich and the poor is becoming more and more obvious. Advanced technology and capital flow to the elite class, which leads to the intensification of the polarization between the rich and the poor in French society. Secondly, the globalization of the market, the development of digital technology and artificial intelligence led to the redistribution of the mode of production in the French labor market, and the sharp rise of the domestic unemployment rate. By 2017, the unemployment rate in France had reached 9.4\%, and 3.5 million of the 29 million working people were unemployed. ("Au troisième trimestre 2017, le produitintérieur brut augmente de $0.6 \%$ ", 2018) The high unemployment rate and the "structural employment contradiction" which is difficult for enterprises to recruit have seriously restricted the development of French economy. 
$32 \%$ of French enterprises believe that the main reason for this problem is that the French vocational education and training system does not export high-skilled talents matching the era of knowledge-based economy. ("France Plans to Reform Apprenticeships", 2018) Finally, there are still drawbacks in the French unemployment insurance system. On the one hand, the system has not played a role in encouraging people to actively obtain employment. Many unemployed people hold unemployment benefits while engaging in "illegal work" without signing contracts and paying taxes. On the other hand, the finance of the National Administration of Unemployment Insurance has lost 3.5 billion Euros since 2017, and the French finance will not be able to continue to support the development of the unemployment insurance system. ("Réforme de la formation professionnelle en 2018: Quels changements majeurs vont se produire dans le futur?", 2018)

\subsection{The Development Needs of Vocational Education and Training System}

Apprenticeship has always been one of the best stepping stones for French labor employment, but in recent years, apprenticeship has gradually lost its attraction to French enterprises and French youth. The main reasons are as follows: 1. Apprentices are both students and employees of enterprises, so they can get salaries from enterprises, but generally $25 \%$ to $80 \%$ of the minimum wage standard (Salaire Minimum Interprofession nel de Croissance, SMIC, 1498.47 Euro/month). Therefore, contemporary French youth are unwilling to face the imbalance between the huge workload of apprentices and the low salary. 2. French enterprises complain that contemporary young people lack hard working attitude and appropriate skills, so they refuse to recruit apprentices. 3. The apprentices in France is seriously inadequate. In recent years, the goal of "cultivating 500,000 apprentices a year" has never been achieved, and in 2017, there is a gap of up to 80,000 apprentices. 4. French society generally believes that apprenticeship is only an alternative to general education. The development of apprenticeship in France was forced to stagnate. ("Edouard Philippe. Le grand plan d'investissment 2018-2022", 2017)

At the same time, the French government will focus on Vocational training, in order to develop the employee's lifelong employability, so as to avoid unemployment at the source. "Enterprises are obliged to invest in employee skills training. Enterprises should predict the future skill needs of each professional field, so as to organize employee innovative skills so as to maintain competitiveness in the increasingly fierce market in the future," said Muriel Peniko. ("Le projet de loi "Avenir Professionnel" présenté en conseil des ministres", 2018) In fact, there are loopholes in the staff training system of French enterprises. Employees have unequal opportunities to receive vocational training, which are mainly reflected in the following three aspects: Firstly, according to the status of employees, the proportion of workers receiving vocational training is $34 \%$, while the proportion of senior managers receiving vocational training is as high as $66 \%$. Secondly, according to the size of enterprises, enterprises with more than 250 employees have $62 \%$ of their employees can receive vocational training. Enterprises with 10 to 19 employees have $44 \%$ of their training probability, while enterprises with 1 to 9 employees have a low probability of training to 3. 5\%. ("France Plans to Reform Apprenticeships", 2018) Thirdly, the existing vocational training system in France is inefficient and opaque, with high training costs and complicated qualification assessment. In the past, France's vocational education and training system has strong attraction in European countries, and the proportion of people receiving training has been far ahead, but according to the latest data, the proportion of young people receiving vocational education in France has dropped to 30\%. ("Française Ministère De Travail. Transformation de La Formation Professionlle", 2018)

\section{Main Contents of Reform}

The popularity of secondary and higher education, the development of vocational education and the wide application of apprenticeship in France have enabled most French people to find a "place" in the increasingly demanding labor market. Nevertheless, the lack of skilled personnel matching the labor market and large-scale unemployment are still major factors affecting French economic development. In order to improve this situation, the French government tries to do something in the following three aspects.

\subsection{Apprenticeship Reform - Training Qualified Personnel}

Timbo Maiel, an economist at the French think tank Industrial Manufacturing, pointed out that France was unable to produce enough highly skilled people because vocational education in France did not provide students with the skills needed by businesses. ("France Plans to Reform Apprenticeships", 2018) Under the dual background of employment difficulties and recruitment difficulties, the French government has focused on the apprenticeship reform.

1. Financing is at the forefront of apprenticeship reform. The Le Center de Formation des Apprentices (CFA) will provide financial assistance according to the size of apprenticeship and the graduation and employment rates of each apprenticeship period, and reduce the apprenticeship tax by $51 \%$ for enterprises (1.6 billion Euros).

2. Increase the welfare of enterprises and apprentices and formulate assistance policies for small and medium-sized enterprises. 
Reduce the burden of apprenticeship and raise the salary of apprentices, increase the salary of apprentices by 30 Euros per month, raise the maximum age of apprentices from 26 to 30 years old. A driver's license subsidy of 500 Euros is provided for apprentices over 18 years of age.

3. Re-planning authority and strengthening training effect. Enterprises will have the power of apprenticeship management and supervision of large regional institutions. Moreover, enterprises must publicize the graduation rate and employment rate of apprentices, and the wage standards of all walks of life will also be made public so that students can have more autonomous choice of courses. The content of apprenticeship teaching and examination is written by enterprises, trying to meet the market demand for skills training.

4. Establish "Le Instituts de Formation Professionnelle" to provide funds for apprenticeship training centers, microsmall and medium-sized enterprises and staff training programs. The organization will also cooperate with relevant institutions to establish an interworking Diploma Mechanism. It also encourages educational innovation and platform innovation of through MOOCs, digital teaching and modular teaching. ("Française Ministère De Travail. Transformation de La Formation Professionlle", 2018)

\subsection{Vocational Training Reform - Avoiding Employees' Unemployment}

In the era of rapid updating of knowledge and skills, vocational training system should strive to keep up with the pace of the times, train the employee's ability of sustainable development and free choice of occupation, and help the employee better adapt to the development of the times. Germany, Britain and other countries vigorously reform their vocational education and training system, actively optimize the labor force, so as to increase productivity and promote economic development. France actively draws on the advanced experience of the two countries and strives to improve its vocational training system.

First, the implementation of the provident fund plan. Trade unions and employers will set up a "Comote Personnel de Formation" (CPF) on the principle of lifelong education. It will change from accumulating training funds according to length of service to depositing 500 Euros into the employee training account directly every year, and cancel the personal training leave (CIF) so that employees can freely choose whether to receive training or not. Employees have more freedom. Secondly, the state subsidizes the collection and apportionment of vocational training fees for enterprises. 11or more workers, the proportion of vocational training levy and assessment fees paid by companies to total wages decreased to $1.68 \%$, and that of 10 or less companies decreased to $1.23 \%$. Since the society for collecting social security contributions and family allowances (Unions de Recouvrement des Cotisations de S curit Sociale et D'allocationed Familiales) will be responsible for collecting assessed fees for Vocational training, enterprises will cancel the management procedures for vocational training fees, thus simplifying the internal administrative mechanism of enterprises. ("Française Ministère du Travail . Document D' orientation", 2017) Thirdly, the professional Career Development Committee (Conseil en volution professionnelle, CPE) is selected by bidding in various regions. The committee will focus on employee skills assessment and supervise employee skills training, so as to ensure equal training opportunities for employees.

Fourthly, the French Skills Agency (French Competences Bureau) was established to control the price of vocational training, supervise the quality of vocational training, ensure the accreditation and funding standards of training institutions, and adjust training costs. The French Skills Agency will invest 15 billion in job seekers and Youth Skills investment programs to provide vocational skills, transferable skills, computer skills and innovative entrepreneurship training for 1 million low-skilled job seekers and 1 million young people in remote areas. Fifth, the introduction of "CPE" mobile applications (APP). Employees can skip the intermediary and learn about each training plan by themselves through this "APP". This "APP" will provide employees with the employment rate of each course, wage situation in all walks of life, the comparison of training cost, and other employees' feedback, so as to give them some reference and help employees to make reasonable curriculum choices. Sixth, micro-small and medium-sized enterprises with a scale of less than 50 people and large enterprises will form a joint financial system. Micro-small and mediumsized enterprises receive vocational training with large enterprises, with training funds provided by large enterprises, and all short-term employees will enjoy the same rights as full-time employees. ("Française Ministère De Travail : Transformation de La Formation Professionlle", 2018)

\subsection{Unemployment Insurance Reform - Promoting Reemployment}

In the process of optimizing the pre-study and mid-employment of the workers' production chain, the French government also pays attention to the unemployment security. The French unemployment insurance system was established at the end of 1958. Its establishment has taken an important step forward in the French social insurance system. 
However, with the transformation of social contradictions, the drawbacks of the system have become increasingly prominent. Therefore, the French government regards the reform of the unemployment insurance system as the top priority of the reform. Its specific contents are as follows:

First, expand the benefit objects of unemployment insurance. Beneficiaries of unemployment insurance will cover selfemployed and resigned workers from workers (craftsmen, entrepreneurs, farmers, etc.). The new unemployment insurance system will provide workers with an opportunity to resign voluntarily and enjoy unemployment insurance benefits every five years. On the issue of unemployment for self-employed, the new unemployment insurance system stipulates that all self-employed can receive an unemployment compensation of 800 Euros per month for six months when they suffer bankruptcy. At the same time, the French government has increased the proportion of self-employed's General Social Insurance Tax (CSG). And government has levied social insurance contributions on enterprises that abuse short-term contracts to avoid paying social insurance premiums, in order to alleviate the financial deficit of the National Unemployment Insurance Administration. Secondly, try out "Job-hunting Diary" for the unemployed, collate and update the unemployed's job-hunting experience, resume and interview information, so as to follow up the jobhunting status, promote the communication between the unemployed and career counselors, and prevent the unemployed from slack job-hunting. "Unemployment insurance is a powerful social security mechanism, but some people abuse this benefit, which is unfair to both employees and active job seekers," said Muriel Peniko. The French Employment Service Center should "de-list" those who are not actively seeking jobs from the unemployment insurance list and impose severe penalties. ("Le gouvernement prévoit une contributionde $0.3 \%$ pour la formation des demandeurs d'emploi", 2018) Thirdly, the current "Reasonable Occupation" mechanism in France stipulates that the French Employment Service Center has the right to recommend jobs to the unemployed. In order to strengthen employment, the government will refine and strengthen the mechanism of "Reasonable Occupation" according to the individual characteristics and market conditions of the unemployed, so as to formulate a personalized "Reasonable Occupation" mechanism. This reform will make the unemployment insurance mechanism more humane and efficient.

\section{Characteristics of Reform}

The main purpose of the future career reform in France is to enable people to enjoy more employment rights and improve their employability, so as to make them better adapt to the changes in the labor market brought about by digitization, artificial intelligence and the transformation of the ecological environment. ("Française Ministère De Travail: Transformation de La Formation Professionlle", 2018) Therefore, while supporting the realization of the goal, the uniqueness of the reform measures is also prominent.

\subsection{Diversification of reform initiatives}

The reform drastically reformed the French vocational field, mainly involving three aspects: apprenticeship reform, vocational training reform and unemployment insurance reform. These three reform measures are all-round and integrated to "escort" individual career. Moreover, the reform plan strives to achieve the vision of everyone benefiting from the reform by simplifying apprenticeship and vocational training paths, increasing training opportunities for apprentices and employees, increasing financial subsidies, and standardizing the application procedures for unemployment insurance. The progress of science and technology provides an opportunity for school vocational education to share resources with the outside world. Schools use information technology to set up distance education and course-admiring education, so as to realize the sharing of high-quality resources in colleges and universities. At the same time, the government has strengthened the participation of enterprises in the field of vocational education so as to achieve mutual development between schools and enterprises. To sum up, the reform has formulated measures from the individual level, social level and government level to promote the integration of reform measures.

Lifelong learning is extremely necessary for individuals, organizations or society. Vocational education is closely related to the development of society, economy and science and technology, and can become a model of lifelong education. Many countries around the world are striving to build the integrated, personalized, equal opportunities, flexible and coordinated high-quality vocational education system, such as Germany's current "training-employmentretraining-re-employment" lifelong vocational education system. Lifelong vocational training is closely related to the development of society, economy and science and technology. Vocational training is not only the beginning of a career, but also must run through a person's life. Under the background of lifelong education, vocational education and vocational training also tend to lifelong.

\subsection{Predictability of the Reform Vision}

"Every young person, every employee and every job seeker will be at the helm of their career in the future," said Muriel Peniko. ("Ce que prévoit le "big bang"de la formation professionnelle", 2018) Therefore, the reform measures of the reform plan point to the future. 
In the era of knowledge economy, the sustainable development of individuals is related to the future destiny of the country. The French government, starting with the reform of apprenticeship, encourages educational innovation, predictability of education, predictability of skills and learning platforms. The French government also requires schools and enterprises to predict the skills needed for future market development, encourage employees to participate in vocational training, so as to continuously update their sustainable development employability, so as to help them adapt to the future trend of the labor market and avoid unemployment from the source. The reform of unemployment insurance is more "proactive" and provides "logistical support" for personal career development ahead of time.

Actively improve the talent demand forecasting system, and establish an information platform for government, large regions, enterprises and colleges to communicate. Colleges and universities have increased their research on future career development trends. Enterprises have strengthened their prediction in new and future occupations, timely or early determination of future career development and requirements, and timely response and implementation to the staff vocational training and vocational education.

\subsection{Individualization of reform methods}

With the development of the times, young people are pursuing individualization more and more. Vocational education and vocational training system cannot ignore or erase the differences between individual abilities and personality tendencies.

The reform bill strengthens personalized vocational education, especially the establishment of vocational education that helps to promote talent and ability, and supports everyone to build their own career path. Therefore, the reform bill is based on the ideas of contemporary youth, and incorporates "individualization" into the ranks of reform initiatives to set education standards. Apprenticeship vocational education not only enables students to have more autonomous choice of courses, but also entrust teaching and examination contents to enterprises. let apprentices choose courses according to their wishes, enterprise choose teaching content according to market. On the one hand, it helps to improve the learning enthusiasm of apprentices, on the other hand, it meets the needs of market changes for skills updating.

Vocational training reform has strengthened the individual's autonomous choice of vocational training through the implementation of the provident fund plan, the introduction of mobile "APP". and through tax reduction of enterprises and the inclusion of enterprises in the ranks of "French Skills Bureau" management, efforts to give enterprises more choice, so that enterprises can provide more personality, equal training opportunities to each employee according to the needs of enterprise development.

The development of technology has support the conditions for individualized vocational education and vocational training. In the future, the development of vocational education and training will be "individualized". According to individual needs, different learning plans, learning forms, learning content and learning time are chosen to achieve learning at anytime and anywhere. In support of employment, the unemployment insurance system also provides "personalized" guidance for the unemployed by analyzing the unemployed themselves and the employment market.

\section{Challenges about the Reform}

From the proposal of reform to the final confirmation of the national law to the promulgation, the reform has gone through a heated discussion stage. French society has raised concerns about reform from different angles.

First, reform measures will not guarantee fairness. Although the act decentralizes the management of vocational education and training, it brings enterprises into the management level. However, this reform will make apprenticeship education marketization, which is not conducive to the development of school education. The reform will also affect the regional government's tax revenue and capital allocation, which is not conducive to the regional economic development. "Based on the system size distribution apprentice subsidies" the implementation of the measures, schools and enterprises will greatly reduce the subsidies amount. For the rural area and urban fringe area of the school and enterprise is unfair, these areas is relatively small, the number of apprentices teaching conditions is poorer, need more money to improve the teaching. The open management of apprenticeships and vocational training, as well as the active cooperation and efficiency of various institutions, will also be a big question.

Second, reform measure cannot attend to crucial. The new mechanism of unemployment insurance in France is an alternative discrimination against the unemployed. The essence of strengthening the punishment of "Reasonable Occupation" is to "force" the group with difficulty in employment to accept the job with poor conditions, which does not meet the requirements of free choice of occupation and does not meet the key to solve the employment problem. 
The annual accumulation fund of 500 Euros to 8,000 Euros is not enough to provide financial support for long-term and multiple training (for example, about 5,000 Euros for housekeeping training and 8,000 Euros for interior decoration training). Therefore, the unemployment insurance reform measures to improve the French labor market employment situation, is undoubtedly a drop in the bucket.

Third, reform exacerbates fiscal deficits. The French government will support the reform by reducing taxes, increasing financial subsidies and raising unemployment insurance benefits, which will cost France an additional 140 million Euros, thus exacerbating the fiscal deficit crisis of the government. Since the first oil crisis, the growth rate of the French economy has continued to decline, and the GDP growth rate in 2017 dropped to $0.6 \%$. ("Ce que prévoit le "big bang"de la formation professionnelle", 2018) The French economy is in the stage of recovery in 2018, but whether this fiscal gap can be filled in time will be a big challenge. The unemployment insurance system has played an important role in guaranteeing the basic livelihood of the unemployed and their families, but its negative effects have become increasingly obvious. In order to enjoy unemployment insurance, employees and employers have to pay $2.4 \%$ and $4 \%$ of their net wages as unemployment insurance respectively, which actually increases the burden on employees, increases the labor cost of enterprises and weakens the competitiveness of enterprises. Sound unemployment insurance also makes some unemployed people choosy and unwilling to find new jobs. At the same time, the high unemployment rate makes unemployment insurance unable to make ends meet. In order to basically balance the income and expenditure of unemployment insurance by the end of 2019, the government has to take new measures to promote the employment of the unemployed.

\section{Référence}

Au troisième trimestre 2017, le produitintérieur brut augmente de $0.6 \%$ [EB/OL].https://www.insee.fr/fr/stati stiques/3294245,2018-7-25.(July 28,2017)

Conceil d'Orientation d'Emploi Synthèse du rapport, automatisation, numérisation et emploi[R]. Paris: Conceil d'Orientation d'Emploi, 2017: 2.

Ce que prévoit le "big bang"de la formation professionnelle.[EB/OL].http://www.nouvelobs.com/ soc iete/social/ceque-prevoit-le-big-bang-dela-formation-professionnelle.html(August 28,2018)

Edouard Philippe(2017). Le grand plan d'investissment 2018-2022[R].Novembre,2017.

Française Ministère De Travail(2018). Transformation de La Formation Professionlle[R].Mars ,2018.

Française Ministère du Travail(2017) . Document D'orientation[R]. Novembre, 2017.

France Plans to Reform Apprenticeships [EB/OL].http://zj.people.com.cn/GB/n2/2018/0518.html (May 18,2018)

Le gouvernement prevoit une contributionde $0.3 \%$ pour la formation des demandeurs demploi [EB/OL].http://cf dtsigma.over -blog.com.html(July 7,2018)

Le projet de loi “Avenir professionnel” présenté en conseil des ministres[EB/OL]. https://www. Caissede sdepotsdesterritoires.fr/cs/ContentServer? 1250281018630(July 25,2018)

Réforme de la formation professionnelle en 2018:Quels changements majeurs vont se produire dans le futur? [EB/OL].http://acifop-formation.com/Reforme-de-la-Formation-synthese-du-projet -de-Loi (May 18,2018) 